\title{
THEORETICAL AND METHODOLOGICAL ASPECTS OF THE ANTI-CRISIS CAPACITY OF ENTERPRISES
}

\author{
Pavlo Ilchuk' ${ }^{1}$, Petro Viblyi², Iryna Lashchyk ${ }^{3}$ \\ Lviv Polytechnic National University, Ukraine
}

\begin{abstract}
The main task of any economic entity in the context of crisis development is the timely development of anti-crisis measures, as well as the assessment of the ability to implement them in order to reduce the risk of bankruptcy and liquidation. An important place in the process of anti-crisis management in particular and the system of anti-crisis management in general is occupied by an anti-crisis capacity, the assessment of which allows determining the expediency of realization of anti-crisis measures and assessing their potential success. The problems of crisis development of enterprises and anti-crisis management are devoted to many scientific works of both domestic and foreign economists, among which the following should be noted: Larionova K.L., Ligonenko L.O., Shankret A.M., Suganiak M.V., Kovalenko V.V., Kamneva A.V., Shershnyova Z.E., Kuzmin O.Ye., Melnyk O.G., Alekseev I.V. Among the works of the abovementioned domestic and foreign economists, practically no work is devoted to the anti-crisis capacity of the company, which underlies any anti-crisis plan, and the success of its implementation depends on the results of its evaluation. The subject of the research is a set of theoretical, methodological, and applied principles of the anti-crisis capacity of enterprises. Methodology. In this research, the following general scientific methods have been used: systematization and generalization (in clarifying the essence of the concept of "anti-crisis capacity of the enterprise"); analogies, generalizations, and groupings (in the development of the classification of anti-crisis capacity of enterprises); economic-mathematical modelling (in forming the indicators' system for assessing the anti-crisis capacity of the enterprise). The purpose of the article is to determinate the importance and necessity of assessing the anti-crisis capacity of the enterprise in terms of crisis development and anti-crisis management in general. Results. In the article, the essence and significance of the anti-crisis capacity of enterprises have been defined as an integral part of the anti-crisis management. It was established at what stage of the anti-crisis management process, the enterprise's anti-crisis capacity should be assessed. Two types of the anticrisis capacity of the enterprise were singled out, for each of them the essence was determined and the estimation method was proposed. The importance and necessity of assessing the enterprise's anti-crisis capacity in the context of anti-crisis management were substantiated in order to choose the optimal variant of anti-crisis measures and, accordingly, avoid bankruptcy and liquidation in the future.
\end{abstract}

Key words: crisis, anti-crisis management, anti-crisis capacity, nature, types, factors, evaluation method.

JEL Classification: G01, C52

\section{Introduction}

Negative trends in the indicators of domestic enterprises' development and the national economy as a whole are a sign of imperfection and the absence of anti-crisis management mechanisms, which is the main component of the anticrisis management system of each economic entity. First of all, these trends become obvious in the inconsistency with the norms and the deterioration in the financial values and operating performance indicators, namely: a significant excess of the enterprise liabilities over its revenues, a mismatch in the norm and a deterioration in the profitability indicators, unprofitable activity, a decline in labour productivity, low level of product competitiveness, etc. (Kovalenko, 2013). A consequence of the abovementioned problems in the activity of the enterprise is a crisis condition, which overcoming requires an immediate activation of the anti-crisis management process. At the same time, the possibility of implementation and success of the anti-crisis management process will depend on the anti-crisis capacity of the enterprise, which is studied in the article.

\footnotetext{
Corresponding author:

${ }^{1}$ Department of Management Technology, Lviv Polytechnic National University.

E-mail: pavlo.g.ilchuk@lpnu.ua

${ }^{2}$ Department of Finance, Lviv Polytechnic National University, Ukraine.

E-mail: petro.i.viblyi@lpnu.ua

${ }^{3}$ Department of Finance, Lviv Polytechnic National University, Ukraine.

E-mail: Iryna.I.Topii@lpnu.ua
} 
The success of enterprise anti-crisis management, first of all, depends on the effectiveness and timeliness of the implementation of anti-crisis measures. Evaluation of the anti-crisis capacity of the enterprise will allow choosing the best variant of anti-crisis measures and, accordingly, overcoming the crisis situation with the least time and resources.

For today, the problem of anti-crisis management is sufficiently developed and studied by both foreign and domestic scientists. Among economists, whose research is related to the theoretical aspects of the anticrisis management process, namely, its essence, features, tasks, functions, and principles, we should mention such as Kovalenko V.V., Suhaniaka M.V., Fuchedzhy V.I., Yepifanova I.Yu., Sytnyk L.S., Vasylenko V.O., Larionova K.L., Lihonenko L.O., Shtanhret A.M., Esh S.M., Zhurlov A.M., Krush P.V., Shershnova Z.Ye., Ohloblina V.O., Ramazanov S.V., Utkin Ye.A., Blank O.I., and others.

Another part of the research is directly related to the methodological basis of anti-crisis management, in particular, the diagnosis of the crisis and bankruptcy of the enterprise. Scientists have developed and improved a significant number of fundamental and express diagnostics, adapted to the activities of domestic enterprises. Among the researchers of this problem should be mentioned such as Kamneva A.V., Nosan N.S., Kuzmin O.Ye., Melnyk O.H., Bondarchuk M.K., Kozyk V.V., Bulieiev I.P., Lysenko O.A., Kyrychenko K.T., Yershova N.Yu., Sytnyk L.S., Pererva P.H., Tereshchenko O.O., Koval H.I., and many others.

Despite the excellence of the above-mentioned economists' works in the field of anti-crisis management, the issues of the enterprise's anti-crisis capacity remain unexplored, which determines the possibility and success of implementing the anti-crisis program and occupies one of the leading positions in the overall system of anti-crisis management of the enterprise.

The article is aimed at determining the importance and necessity of assessing the anti-crisis ability of an enterprise in the conditions of crisis development and anti-crisis management in general. Accordingly, the research objective is to substantiate the nature and characteristics of the enterprise's anti-crisis capacity, as well as its types and methods of evaluation.

\section{State and trends of domestic enterprises development}

As noted above, in recent years, domestic enterprises have been unstable under conditions of uncertainty and increased risk, which often results in their crisis, bankruptcy, and liquidation. At the same time, not only the indicators of their internal basic and financial activities deteriorate but also the external economic one (Topiy, 2010). Confirmation of this is the indicators of the state of domestic industrial enterprises development, which we divided into three groups, namely, external, internal, and legal (Table 1).

According to Table 1, most of the external indicators of the development of industrial enterprises are deteriorating in the dynamics, which indicates a low level of competitiveness of domestic products and unsatisfactory market positions of its producers. No less negative tendencies are observed in relation to internal indicators of activity of industrial enterprises. By the end of 2017, the decline in the number of industrial enterprises was accompanied by an increase in losses by $5.7 \%$, a decrease in sales volumes by $4.5 \%$ and, consequently, an increase in the loss-making rate by $9.8 \%$.

A number of legal indicators also testify to the deterioration of the activity of domestic industrial

Table 1

Dynamics of external, internal, and legal indicators of domestic industrial enterprises development for the period of 2014-2017

\begin{tabular}{|c|c|c|c|c|c|c|c|}
\hline \multirow{2}{*}{ Indicators } & \multicolumn{4}{|c|}{ Years } & \multicolumn{3}{|c|}{ Deviations, \% } \\
\hline & 2014 & 2015 & 2016 & 2017 & $2015 / 2014$ & $2016 / 2015$ & $2017 / 2016$ \\
\hline \multicolumn{8}{|c|}{ External indicators } \\
\hline Industry index of production, $\%$ & 102,8 & 103,7 & 100,8 & 99,9 & 0,8 & $-2,8$ & $-0,9$ \\
\hline Exports of goods, billion USD & 53,9 & 31,6 & 25,1 & 39,4 & $-41,3$ & $-92,1$ & 56,9 \\
\hline Imports of goods, billion USD & 54,4 & 31,2 & 31,2 & 44,6 & $-42,6$ & 0 & 42,9 \\
\hline \multicolumn{8}{|c|}{ Legal indicators } \\
\hline Number of initiated bankruptcy cases, units & 3324 & 2406 & 2418 & 2423 & $-27,6$ & 0,5 & 0,2 \\
\hline $\begin{array}{l}\text { With the approval of the liquidation report, } \\
\text { units }\end{array}$ & 2989 & 2159 & 2122 & 2124 & $-27,7$ & $-1,7$ & 0,09 \\
\hline $\begin{array}{l}\text { With the approval of the report on } \\
\text { recognition of a bankrupt enterprise, units }\end{array}$ & 2095 & 1799 & 1756 & 1770 & $-14,1$ & $-2,4$ & 0,8 \\
\hline \multicolumn{8}{|c|}{ Internal indicators } \\
\hline Net loss, billion UAH & 590,1 & 373,5 & 367,1 & 388,2 & $-36,71$ & $-1,71$ & 5,75 \\
\hline Volume of sales, billion UAH & 4170,7 & 4973,4 & 5159,1 & 4926,8 & 19,2 & 3,7 & $-4,5$ \\
\hline Losses of the main activity, \% & 14,1 & 7,5 & 7,1 & 7,8 & $-46,81$ & $-5,33$ & 9,86 \\
\hline
\end{tabular}

Source: created by the authors on the basis of (Vyshnevska, 2016 - Vyshnevska, 2017) 
enterprises. So, at the end of the analysed period, all the examined indicators increased, which indicates the imperfection of mechanisms of anti-crisis management, which should come into effect during the crisis development of enterprises, an integral part of which is their anti-crisis capacity.

\section{The essence and significance of the enterprise's anti-crisis capacity}

We offer to understand the anti-crisis capacity of the enterprise as the availability of resources (financial, material, labour, etc.) from the enterprise or possible sources of their attraction in volumes sufficient to implement anti-crisis measures and achieve the set goals.

For a better understanding of the essence and significance of the enterprise's anti-crisis capacity, we should determine its place in the overall system of anticrisis management.

The system of anti-crisis management of an enterprise is a set of clearly defined and interconnected elements, which purpose is to preserve the enterprise's value of the unit in conditions of negative impact of internal and external environmental factors of functioning (Topiy, 2010). The system of anti-crisis management of the enterprise is closely related to the endogenous and exogenous environment of the enterprise, which conditions and factors directly affect the features and sequence of implementation of the elements of the system.

Common elements of the enterprise anti-crisis management system are: resource support of the enterprise, principles which should be the basis of anticrisis management, subjects that will directly influence the objects and results of the anti-crisis management through the anti-crisis management process. Components of the anti-crisis management process are: the technology of anti-crisis management; methods of anti-crisis management; anti-crisis management decisions. The technology of anti-crisis management assumes a consistent implementation of the functions of anti-crisis management, namely: planning, organization, motivation, control, and regulation.

It is during the implementation of the planning function, which provides for the establishment of anticrisis management objectives and the development of anti-crisis measures that the anti-crisis capacity of the enterprise, that is, its ability to implement the developed measures, should be assessed.

We propose to divide the anti-crisis capacity into resource and time ones. Anti-crisis resource capacity can be financial, material, labour, and other. The evaluation of a particular anti-crisis capacity is determined by the nature of the crisis and the peculiarity of the enterprise's activities.

Let's consider the essence and methods of calculating each type of the anti-crisis capacity of the enterprise in more details.
Anti-crisis resource capacity is the capability of an enterprise to implement the developed anti-crisis measures within the limits of its own or attracted resources. The most common is the study of anti-crisis financial (the capability to implement developed anticrisis measures based on own or attracted financial resources), material (the capability to implement developed anti-crisis measures based on own or attracted material resources), labour (adequacy, capability, and readiness of enterprise employees to implement the developed anti-crisis measures) and information capacity (availability of information (information resources)), which volume and reliability is sufficient to implement the developed anti-crisis measures), as a composite anti-crisis resource capacity. Anti-crisis time ability characterizes the enterprise's capability to implement the developed anti-crisis measures for a clearly defined period.

The methods of assessing each type of anti-crisis capacity are shown in Table 2 .

\section{The practical significance of the enterprise's anti-crisis capacity}

The methodology for interpreting the results of assessing the enterprise's anti-crisis capacity is given in Table 3.

According to the results of the analysis of the financial condition of PrAT "Lvivskyi Instrumentalnyi Zavod" for 2015-2017, all signs of a crisis situation were discovered. Therefore, it was decided to approbate a methodology for assessing the level of anti-crisis capacity of an enterprise on the example of PrAT "Lvivskyi Instrumentalnyi Zavod" (Sait PAT «Lvivskyi instrumentalnyi zavod»).

In order to assess the anti-crisis ability of the enterprise, let us consider the possibility of introducing two alternative anti-crisis measures:

1) implementation of an investment project to diversify activities by mastering new types of production (hereinafter referred to as the anti-crisis measure 1);

2) formation of its own distribution network (hereinafter referred to as the anti-crisis measure 2);

3) modernization of the main production line (hereinafter referred to as anti-crisis measure 3).

The initial data and the results of the assessment of the general anti-crisis resource capacity of PrAT "Lvivskyi Instrumentalnyi Zavod" of anti-crisis measures 1-3 are presented in Table 4.

Based on the results of the evaluation of the anti-crisis resource capacity of measures, the anti-crisis measure 3 does not correspond to the necessary conditions, since the ratio of $A_{c}^{\text {rgen }}<1$, and therefore, the measure is not implemented and is rejected. While the other two anticrisis measures correspond to the necessary conditions for the implementation, and for them, the anti-crisis time capacity will be assessed. 
Vol. 4, No. 3, 2018

Table 2

Calculation formulas for assessing the anti-crisis capacity of an enterprise

\begin{tabular}{|c|c|c|}
\hline Indexes & $\begin{array}{c}\text { Formulas for } \\
\text { calculations }\end{array}$ & Characteristic \\
\hline $\begin{array}{l}\text { Anti-crisis capacity of an } \\
\text { enterprise }\end{array}$ & $\mathrm{A}_{\mathrm{c}}=\mathrm{A}_{\mathrm{c}}^{\mathrm{rgen}} \times \mathrm{A}_{\mathrm{c}}^{\mathrm{t}}$ & $\begin{array}{l}A_{c}^{r g e n}-\text { an indicator of the general anti-crisis resource capacity of the enterprise, part of } \\
\text { the unit; } A_{c}^{t} \text {-the indicator of anti-crisis time capacity of the enterprise, part of the unit. }\end{array}$ \\
\hline $\begin{array}{l}\text { General anti-crisis resource } \\
\text { capacity of an enterprise }\end{array}$ & $\mathrm{A}_{\mathrm{c}}^{\mathrm{rgen}}=\sqrt[n]{\prod_{\mathrm{i}=1}^{\mathrm{n}} \mathrm{A}_{\mathrm{c}}^{\mathrm{ri}}}$ & $\begin{array}{l}\mathrm{A}_{\mathrm{c}}^{\mathrm{ri}} \text { - the anti-crisis capacity of the i-th type of resource, part of the unit; i - kind of } \\
\text { resource used by the enterprise; } \mathrm{n} \text { - the number of resources used by the enterprise. }\end{array}$ \\
\hline $\begin{array}{l}\text { Anti-crisis capacity of an } \\
\text { i-th type of resource }\end{array}$ & $\mathrm{A}_{\mathrm{c}}^{\mathrm{ri}}=\frac{\mathrm{R}_{\mathrm{av}}^{\mathrm{i}}+\mathrm{R}_{\mathrm{at}}^{\mathrm{i}}}{\mathrm{R}_{\mathrm{am}}^{\mathrm{i}}}$ & $\begin{array}{l}\mathrm{R}_{\mathrm{av}}^{\mathrm{i}} \text { - the amount of available in the enterprise } \mathrm{i} \text {-th type of resource, necessary for } \\
\text { the implementation of anti-crisis measures in natural or in monetary form; } \mathrm{R}_{\mathrm{at}}^{\mathrm{i}}-\text { the } \\
\text { volume of the } \mathrm{i} \text {-th type of resource that an enterprise can attract for the implementation } \\
\text { of an anti-crisis measure in the natural or monetary form; } \mathrm{R}_{\mathrm{am}}^{\mathrm{i}} \text { - the volume of the } \mathrm{i} \text {-th } \\
\text { type of resource required for the implementation of an anti-crisis measure in the natural } \\
\text { or monetary form; } \mathrm{i} \text { - kind of resource (material, financial, labour, others); } \mathrm{i}=1, \mathrm{n} \text {; } \\
\mathrm{n} \text { - number of resources necessary for the implementation of the anti-crisis measure. }\end{array}$ \\
\hline Anti-crisis time capacity & $\begin{array}{l}\text { a) } \mathrm{A}_{\mathrm{c}}^{\mathrm{t}}=\frac{\mathrm{S}_{\mathrm{c}}}{\mathrm{S}_{\mathrm{am}}} \\
\text { 6) } \mathrm{A}_{\mathrm{c}}^{\mathrm{t}}=\frac{\mathrm{T}^{\mathrm{b}}}{\mathrm{S}_{\mathrm{am}}} \\
\text { a6o } \\
\mathrm{A}_{\mathrm{c}}^{\mathrm{t}}=\frac{160}{\mathrm{~S}_{\mathrm{am}}}\end{array}$ & $\begin{array}{l}\mathrm{S}_{\mathrm{c}} \text { - speed of the problem situation development or the period allocated } \\
\text { for the implementation of the anti-crisis measures, days; } \mathrm{S}_{\mathrm{am}} \text { - speed of the } \\
\text { implementation of the anti-crisis measure or the period for which the enterprise can } \\
\text { implement the anti-crisis measures and solve the problem situation, days; } \\
\mathrm{T}^{\mathrm{b}} \text { - the period remaining until the announcement of the enterprise bankrupt, } \\
\text { days; } 160 \text { - number of days till the bankruptcy proceedings, if the day when the } \\
\text { debtor fails to fulfil his obligations to the creditor is a starting point. }\end{array}$ \\
\hline
\end{tabular}

Source: created by the authors

Table 3

Interpretation scale for the enterprise crisis assessment results

\begin{tabular}{|c|c|}
\hline Scale & Reasoning \\
\hline \multicolumn{2}{|r|}{ Necessary conditions for the anti-crisis capacity } \\
\hline $\mathrm{A}_{\mathrm{c}}^{\mathrm{rgen}} \geq 1$ & $\begin{array}{l}\text { An enterprise is able to implement the developed anti-crisis measure within the limits of available and attracted } \\
\text { resources, in the future it is necessary to evaluate the anti-crisis time capacity of the event }\end{array}$ \\
\hline $\mathrm{A}_{\mathrm{c}}^{\mathrm{rgen}}<1$ & $\begin{array}{l}\text { An enterprise is unable to implement the developed anti-crisis measure within the available and attracted resources, so } \\
\text { the measure is rejected and to assess the anti-crisis time capacity of the event in the future is inappropriate }\end{array}$ \\
\hline \multicolumn{2}{|r|}{ Sufficient conditions for the anti-crisis ability capacity } \\
\hline $\mathrm{A}_{\mathrm{c}}^{\mathrm{t}} \geq 1$ & An enterprise is able to implement the developed anti-crisis measure within the available time \\
\hline $\mathrm{A}_{\mathrm{c}}^{\mathrm{t}}<1$ & $\begin{array}{l}\text { An enterprise is unable to implement the developed anti-crisis measure within the available time, so the measure is } \\
\text { rejected since the bankruptcy will come earlier than the expected results of the implementation of the anti-crisis measure } \\
\text { will be received }\end{array}$ \\
\hline \multicolumn{2}{|r|}{ Choice of anti-crisis measure } \\
\hline \multicolumn{2}{|c|}{$\begin{array}{l}\text { From the developed anti-crisis measures for implementation, the one with the } A_{c} \text { level in the maximum, that is, the function } \\
A_{c} \rightarrow \max ; A_{c}>0 \text { is valid }\end{array}$} \\
\hline \multicolumn{2}{|r|}{ Levels of the anti-crisis capacity } \\
\hline $\mathrm{A}_{\mathrm{c}}>2$ & $\begin{array}{l}\text { High level of the anti-crisis capacity (an enterprise is capable, within the limits of available and/or attracted resources and } \\
\text { time, of implementing the developed plan for anti-crisis measures, having considerable resources of resources and time, } \\
\text { guarantees the implementation of the anti-crisis measure) }\end{array}$ \\
\hline $1 \leq \mathrm{A}_{\mathrm{c}} \leq 2$ & $\begin{array}{l}\text { The optimal level of anti-crisis ability (an enterprise is able to implement a developed plan of anti-recessionary measures, } \\
\text { with available resources and time within the limits of available and/or attracted resources and time, significantly increases } \\
\text { the probability of implementing an anti-crisis measure) }\end{array}$ \\
\hline $1 \leq \mathrm{A}_{\mathrm{c}}<1,5$ & $\begin{array}{l}\text { Admissible level of anti-crisis ability (an enterprise is able to implement the developed plan of anti-crisis measures in case } \\
\text { of attracting additional resources and deferring debts to creditors) }\end{array}$ \\
\hline $\mathrm{A}_{\mathrm{c}}<1$ & $\begin{array}{l}\text { Unsatisfactory level of anti-crisis ability (an enterprise is not able to implement anti-crisis measures within available } \\
\text { resources and time) }\end{array}$ \\
\hline
\end{tabular}

Source: created by the authors 
Table 4

Results of the assessment of the general anti-crisis resource capacity of PrAT "Lvivskyi Instrumentalnyi Zavod" of planned anti-crisis measures

\begin{tabular}{|c|c|c|c|c|}
\hline Types of resources & $\mathrm{R}_{\mathrm{av}}^{\mathrm{i}}$ & $\mathrm{R}_{\mathrm{at}}^{\mathrm{i}}$ & $\mathrm{R}_{\mathrm{am}}^{\mathrm{i}}$ & $\mathrm{A}_{\mathrm{c}}^{\mathrm{ri}}$ \\
\hline \multicolumn{5}{|c|}{ Anti-crisis measure 1} \\
\hline Material, thousand UAH & 620 & 320 & 931 & 1,01 \\
\hline Labour, people & 10 & 6 & 13 & 1,23 \\
\hline Financial, thousand UAH & 108 & 500 & 451 & 1,35 \\
\hline Intangible, thousand UAH & 0 & 30 & 25 & 1,20 \\
\hline Information, thousand UAH & 3 & 2 & 3 & 1,67 \\
\hline Total anti-crisis resource capacity of measure $\mathrm{A}_{\mathrm{c}}^{\mathrm{rgen}}$ & \multicolumn{4}{|c|}{1,27} \\
\hline \multicolumn{5}{|c|}{ Anti-crisis measure 2} \\
\hline Material, thousand UAH & 310 & 120 & 372 & 1,16 \\
\hline Labour, people & 6 & 10 & 15 & 1,07 \\
\hline Financial, thousand UAH & 81 & 96 & 176 & 1,01 \\
\hline Intangible, thousand UAH & 1 & 19 & 20 & 1,00 \\
\hline Information, thousand UAH & 3 & 1 & 3 & 1,33 \\
\hline Total anti-crisis resource capacity of measure $\mathrm{A}_{\mathrm{c}}^{\text {rgen }}$ & \multicolumn{4}{|c|}{1,11} \\
\hline \multicolumn{5}{|c|}{ Anti-crisis measure 3} \\
\hline Material, thousand UAH & 465 & 200 & 651 & 1,02 \\
\hline Labour, people & 7 & 5 & 12 & 1,00 \\
\hline Financial, thousand UAH & 125 & 100 & 361 & 0,62 \\
\hline Intangible, thousand UAH & 1 & 8 & 14 & 0,64 \\
\hline Information, thousand UAH & 3 & 1 & 3 & 1,33 \\
\hline Total anti-crisis resource capacity of measure $A_{c}^{\text {rgen }}$ & \multicolumn{4}{|c|}{0,89} \\
\hline
\end{tabular}

Source: created by the authors on the basis of materials by PrAT "Lvivskyi Instrumentalnyi Zavod"

A separate stage in assessing the enterprise's anti-crisis capacity is to determine the anti-crisis time capacity. The initial data and the results of the assessment of the anti-crisis time capacity PrAT "Lvivskyi Instrumentalnyi Zavod” of anti-crisis measures 1 and 2 are presented in Table 5 .

Table 5

Evaluation results of the anti-crisis time capacity of PrAT "Lvivskyi Instrumentalnyi Zavod" of planned anti-crisis measures

\begin{tabular}{|c|c|c|c|}
\hline $\begin{array}{c}\text { Types of anti-crisis } \\
\text { measures }\end{array}$ & $\mathrm{S}_{\mathrm{c} \text {, days }}$ & $\mathrm{S}_{\mathrm{am} \text {, days }}$ & $\mathrm{A}_{\mathrm{c}}^{\mathrm{t}}$ \\
\hline Anti-crisis measure 1 & 180 & 270 & 0,67 \\
\hline Anti-crisis measure 2 & 180 & 120 & 1,50 \\
\hline
\end{tabular}

Source: created by the authors on the basis of materials by PrAT "Lvivskyi Instrumentalnyi Zavod"

Based on evaluation results of the anti-crisis time capacity ofmeasures, the anti-crisis measure 1 does not correspond to sufficient conditions since the ratio of $\mathrm{A}_{c}^{t}<1$, and therefore, the measures are not implemented and are rejected.

Based on assessment results of the general anti-crisis resource capacity and the anti-crisis time capacity of PrAT "Lvivskyi Instrumentalnyi Zavod", data were obtained to assess the anti-crisis capacity of the enterprise and determine its level. The calculating results of the anti-crisis capacity level of PrAT "Lvivskyi Instrumentalnyi Zavod” are presented in Table 6.
Table 6

Anti-crisis capacity level of PrAT "Lvivskyi Instrumentalnyi Zavod"

\begin{tabular}{|c|c|c|c|c|}
\hline $\begin{array}{c}\text { Types of anti-crisis } \\
\text { measures }\end{array}$ & $\mathrm{A}_{\mathrm{c}}^{\text {rgen }}$ & $\mathrm{A}_{\mathrm{c}}^{\mathrm{t}}$ & $\mathrm{A}_{\mathrm{c}}$ & $\begin{array}{c}\text { Anti-crisis } \\
\text { capacity level }\end{array}$ \\
\hline Anti-crisis measure 2 & 1,11 & 1,50 & 1,66 & Optimal \\
\hline
\end{tabular}

Source: created by the authors on the basis of materials by PrAT "Lvivskyi Instrumentalnyi Zavod"

Based on the assessment of the anti-crisis capacity of PrAT "Lvivskyi Instrumentalnyi Zavod” of planned anti-crisis measures, it can be stated that the enterprise has an optimal level of anti-crisis capacity in order to implement the anti-crisis measure 2 . Thus, the only alternative of the anti-crisis measure considered for implementation by PrAT "Lvivskyi Instrumentalnyi Zavod" in the future is the anti-crisis measure 2, which will ensure the overcoming of the crisis, because the enterprise is able to implement the developed anti-crisis measure 2 within existing and/or attracted resources and time, having a significant reserve of resources and time, significantly increases the likelihood of the implementation of such an event.

It should be noted that for the effective operation of any business entity, the availability of material, financial, labour, and other resources is not sufficient, because it is necessary to own the technologies for their attraction and use. 


\section{Conclusions}

The results of the conducted researches showed that the anti-crisis capacity of an enterprise is an important component of the anti-crisis management process, which effectiveness and performance of the evaluation determines the success and prospects of the enterprise as an integrated business unit. It was determined that the anti-crisis capacity of the enterprise should be evaluated at the initial stages of anti-crisis management, in particular, at the stage of implementing the planning function. Evaluation of the enterprise's anti-crisis capacity allows making the right decision regarding the type and directions of anti-crisis actions and, accordingly, avoiding a number of risks that may become the reasons for its bankruptcy and liquidation in the future. A promising area for further research will be the identification of factors of anti-crisis capacity, the classification of their types and the degree of impact.

\section{References:}

Kovalenko V.V., Suganiaka M.V., Fuchedzhi V.I. (2013). Antykryzove finansove upravlinnia v systemi subiektiv ekonomichnoi dialnosti [Anticrisis finance management in system of subject of economic activity: methods and instrument of evaluation]. Odesa. (in Ukrainian)

Yepifanova I.Yu. (2015). Sutnist antykryzovogo upravlinnia pidpruemstvom [The essence of the crisis management of the company]. Economika $i$ suspilstvo, № 1, pp. 265-269. Retrieved from: http://economyandsociety.in.ua (in Ukrainian)

Kamneva A.V. (2014). Doslidzhennia isnuiuchykh instrumentiv ta modelei antykryzovogo upravlinnia na pidpryiemstvi [A study of existing tools and models of crisis management in the enterprise]. Economika ta ypravlinnia pidpryemstvamy mashynobydivnoi haluzi, № 4, pp. 15-27. (in Ukrainian)

Nosan N.S. (2016). Adaptatsia yevropeiskoho dosvidu funktsionuvania mekhanizmu bankrutstva pidpryiemstv u vitchyznianii praktytsi [Adaptation of the European experience of functioning of the mechanism of bankruptcy of enterprises in domestic practice]. Investytsii: praktyka ta dosvid, № 18, pp. 52-56. (in Ukrainian)

Topiy I.I. (2010). Teoretyko-metodologichnyi pidkhid do pobudovy modeli protsesu antykryzovogo upravlinia mashynobudivnym pidpryiemstvom [Theoretical and methodological approach to construction of the model of the crisis management system by the machine-building enterprise]. Investytsii: praktyka ta dosvid, № 20, pp. 52-56. (in Ukrainian)

Vyshnevska O.A. (Eds.). (2016). Statystychnyi biuleten: za sichen-serpen 2016 r. [Statistical Bulletin: JanuaryAugust 2016]. Kyiv: Derzhkomstat Ukrainy. (in Ukrainian)

Vyshnevska O.A. (Eds.). (2017). Statystychnyi biuleten: za sichen-serpen 2017 r. [Statistical Bulletin: JanuaryAugust 2017]. Kyiv: Derzhkomstat Ukrainy. (in Ukrainian)

Sait PAT «Lvivskyi instrumentalnyi zavod» [The site of PJSC «Lviv Instrumental Zavod»]. Retrieved from: http://liz.pat.ua/ (in Ukrainian) 